\title{
The feeling of timelessness: Russian right-wing radical thought of the turn of the XIX-XX centuries between the horizons of the past and the future of Russia
}

\author{
O. Y. Kazenkov ${ }^{1}$
}

1P. G. Demidov Yaroslavl State University, 14 Sovetskaya str., Yaroslavl 150003, Russian Federation

DOI: $10.18255 / 2412-6519-2021-3-228-239$

Research Article

Full text in Russian

This article is devoted to the problem of the development of the Russian right-wing radical ideology before and at the beginning of the 1905 Revolution. The author analyzes the papers of some representatives of this political movement in Russia, tracing the process of evolution of their views from utopian to quite clearly politically meaningful and aimed at solving the social, political and economic problems of Russia that were relevant for that time. The purpose of the article is to show the diversity and contradictions in the system of views of right-wing radicals in Russia at the beginning of the XX century. The author comes to the conclusion that the reforms of S. Yu. Witte had a significant impact on the development of right-wing radicalism in Russia, and during the formation of oppositional views towards them, a strongly updated political platform of right-wing radicalism in Russia at the beginning of the XX century emerged. The author attributes these contradictions to the assessment of the Russian monarchy and the ways of Russia's development/ .The author shows that the right-wing radicals considered Russia at the beginning of the XX century as a country with a sick economy and political system, they opposed the import of institutions from the West, considering the Russian civilization to be quite complete and self-sufficient.

Keywords: the right-wing radicalism in Russia; far-right political thought; S. Y. Witte's reforms; right-wing opposition; the 1905 Revolution; Russian conservatism; Russian nationalism; Russian political thought

INFORMATION ABOUT THE AUTHORS

Kazenkov, Oleg Y. | E-mail: o.kazenkov@gmail.com

For citation: Kazenkov O. Y. The feeling of timelessness: Russian right-wing radical thought of the turn of the XIX-XX centuries. between the horizons of the past and the future of Russia // Social'nye i gumanitarnye znanija. 2021. Vol. 7, No 3. P. 228-239. (in Russ.)

(C) Kazenkov O. Y., 2021

This is an open access article under the CC BY license (https://creativecommons.org/licenses/by/4.0/) 


\section{Ощущение безвременья: русская правая радикальная мысль рубежа XIX - XX вв. между горизонтами прошлого и будущего России}

\section{О. Ю. Казенков ${ }^{1}$}

1Ярославский государственный университет им. П. Г. Демидова, ул. Советская, 14, Ярославль, 150003, Российская Федерация

Данная статья посвящена проблеме развития правой радикальной идеологии России перед и в начале революции 1905 года. Автор анализирует труды некоторых представителей этого политического движения в России, прослеживая процесс эволюции их взглядов от утопических к вполне четко политически осмысленным и обращенным на решение актуальных для того времени социальных, политических и экономических задач России. Цель статьи заключается в том, чтобы показать разнообразие и противоречия в системе взглядов правых радикалов в России начала XX в. Эти противоречия автор относит к оценке российской монархии и путей развития России. Автор приходит к выводу, что значительное влияние на развитие правого радикализма в России оказали реформы С. Ю. Витте, в ходе формирования оппозиционных по отношению к ним взглядов возникла сильно обновленная политическая платформа правого радикализма в России начала XX в. Автор показывает, что правые радикалы рассматривали Россию начала XX в. как страну с больными экономикой и политической системой, они выступали против импорта институтов с Запада, считая русскую цивилизацию вполне состоявшейся и самодостаточной.

Ключевые слова: правый радикализм в России; ультраправая политическая мысль; реформы С. Ю. Витте; правая оппозиция; революция 1905 года; русский консерватизм; русский национализм; российская политическая мысль

\section{ИНФОРМАЦИЯ ОБ АВТОРАХ}

$$
\begin{array}{l|l}
\text { Казенков, Олег Юрьевич } & \begin{array}{l}
\text { E-mail: o.kazenkov@gmail.com } \\
\text { Почетный работник сферы образования Российской } \\
\text { Федерации, советник ректората }
\end{array}
\end{array}
$$

Для цитирования: Казенков О. Ю. Ощущение безвременья: русская правая радикальная мысль рубежа XIX - XX вв. между горизонтами прошлого и будущего России // Социальные и гуманитарные знания. 2021. Том 7, № 3. С. 228-239.

\section{Введение}

Революции происходят отчасти от смятения интеллектуальной элиты и масс, смятения, вызванного неудовлетворенностью настоящим. Многие революционеры обращались в своих исследовательских поисках к прошлому, где они видели «золотой век», с потерей которого для общества начались его беды [1]. Но было ли это присуще только радикалам, стремившимся разрушить государственный порядок? Далеко нет,

(C) Казенков О. Ю., 2021

Статья открытого доступа под лицензией СС BY (https://creativecommons.org/licenses/by/4.0/) 
и сам политический радикализм далеко не всегда подразумевает планирование нанести удар по государству и по его центральным органам управления. Правый радикализм во многих странах ставил и ставит задачу сотрудничества с государством, чтобы взять под контроль власть, так было в России начала XX в. [2].

Русский правый радикализм конца XIX - начала XX вв. произошел от славянофильства, но, в отличие от последнего, в нем обнаруживается фокус на негативных сторонах реформ С. Ю. Витте. По сути, правый радикализм не видел в этих реформах только отрицательные аспекты.

Цель настоящей статьи - показать разнообразие и противоречия представлений праворадикальных политических деятелей начала периода правления Николая II с точки зрения их видения развития России в политическом, историческом и экономическом аспектах, представив праворадикальную русскую мысль перед революцией 1905 г. и в ее начале в качестве сложной системы взглядов, на формирование которой оказал влияние, помимо прочих факторов, личный опыт основателей праворадикального движения в России. Это историческое время интересно для нас тем, что практически с 1897 по 1903 гг. Россия находилась, как общепризнанно, на экономическом подъеме, который не имел аналогов ранее. Но предпосылки роста российской экономики возникли еще до 1897 г. На фоне хозяйственных успехов Россия имела достижения в культуре, науке и технике, праве и других сферах. Однако именно в это время наблюдается рост левого и правого радикализма [3, с. 22] как реакция на ускорение развития, правыми это развитие воспринимается в качестве отклонения от цивилизационного пути России, левыми - как период усиления напряжения отношений между трудом и капиталом, когда общество сделало крупный шаг к социальной революции.

Современные российские консерваторы и их предшественники в 1980-1990-е гг. видели «золотой век» России именно в том времени, которое вызывало критики правых радикалов начала XX в. Анализ правой российской мысли прошлого и позапрошлого веков и периода правления Николая II имеет также особую актуальность в силу не прекращающейся в российском обществе дискуссии о цивилизационном суверенитете и особом пути России [4]. Октябрьская революция 1917 г., как и Февральская [5; 6], воспринимается российскими правыми в качестве отклонения от верного пути развития [7], в то время как их идейные коллеги более ста лет назад видели такими вехами в отклонении от истинно русского пути реформы Петра I и С. Ю. Витте, в отказе от наследия которых они видели возврат российского общества на присущий ему и, соответственно, гармоничный путь развития, правда, само развитие русские правые видели смутно.

Надо выделить умеренно правую в современной российской историографии позицию на природу Октябрьской революции и ее предысторию, отраженную в концептуальных идеях В.П. Булдакова и П. В. Волобуева, согласно которой революция была следствием разочарования масс во власти и поиска значительной частью крестьянства и пролетариата новых схем выживания, в результате этого поиска и возник наиболее близкий русскому народу по духу советский строй $[8$, c. $51 ; 9 ; 10]$. Позиция В. П. Булдакова близка ранней евразийской социально-политической мысли, евразийцев следует отнести к русским умеренно правым. Близок к позиции В.П.Булдакова историк В. В. Зверев [11], который видит в ленинском большевизме продолжение народничества.

Задачами в настоящей работе выступают, согласно ее цели, анализ трудов идейных лидеров правого радикализма рубежа XIX-XX вв. в России на предмет видения ими 
кризисов в прошлом и путей выхода из них в будущем, оценка отношения правых русских радикалов к центральной власти и, соответственно, выделение праворадикальных характеристик исторического периода начала правления Николая II. Мы акцентируем внимание на идейно-политических воззрениях основных фигур русского правого радикализма исследуемого периода.

Мы применяем следующие методы исследования: проблемно-хронологический, генетический и биографический.

Правый радикализм в России начала XX в. представляет собой феномен в том смысле, что его ядром стала русская интеллигенция, которая традиционно ассоциируется либо с либералами, либо с социал-демократией, во всяком случае, русская интеллигенция в массовом политическом сознании россиян, сформированном после 1917 г., никак не вписывается в формат ультраправых идеологических течений. Тем не менее социальный состав праворадикального движения в России был в значительной степени представлен гуманитарной интеллигенцией. В то же время правым радикалам начала XX в. нельзя отказать в революционности их идей и планов, только осуществлять они их намеревались без разрушения самого государственного механизма. В этой связи через анализ сведений о биографиях лидеров праворадикального движения в России можно понять причины формирования их философских и политических взглядов. Близко к биографическому находится генетический метод в историческом познании, в данном случае нам важно проследить преемственность и связанность во взглядах различных представителей праворадикальной мысли в России рубежа XIX-XX вв.

\section{Основные тенденции развития дореволюционного правого радикализма в России и концептуальные идеи С. Ф. Шарапова}

Во второй половине XIX в. на Западе шел процесс формирования парламентской демократии, по поводу чего в России возникла дискуссия. которая во многом нашла отражение в трудах М. Н. Каткова $[12$, с. 371; 13], по поводу правого радикализма и бюрократического государства. По его мнению, бюрократия не могла выступать посредником между царем и народом, что особенно стало очевидно в ходе Великих реформ [12, с. 190].

Далее происходит интересный поворот в развитии русской праворадикальной идеологии: в мае 1882 г. министр внутренних дел и известный антисемит Н. П. Игнатьев предложил провести Земский собор (за это он лишился министерского портфеля), на котором представительствовали бы крестьяне, в ответ на убийство Александра II. Н. П.Игнатьев был вдохновлен письмом знаменитого мыслителя и славянофила Ивана Аксакова. У Н. П. Игнатьева был сильный оппонент - Константин Победоносцев, который в 1881 г. занял должность обер-прокурора Священного синода, на ней он пробудет до 1905 г. Таким же противником соборности станет новый министр внутренних дел Дмитрий Толстой. Оба государственных деятеля будут во многом определять официальный консерватизм в Российской империи, этот тип консерватизма являлся противопоставлением государственному либерализму периода правления Александра II, который незадолго до своей гибели готовился предложить обществу проект конституции.

Русский правый радикализм в его независимой форме был отвергнут властью и в значительной степени маргинализировался. Тем не менее труды русских правых радикалов продолжали появляться и вызывать интерес общества, ярким примером 
чему служат работы Сергея Федоровича Шарапова, участника Русского собрания, а затем и одного из организаторов Союза русского народа. По С. Ф. Шарапову, многие беды России начались с реформ Петра I, когда Россия утратила свою уникальную государственность, восприняв западную бюрократию. Разумеется, С. Ф. Шарапов критиковал и начавшийся с Петра I путь социально-экономического развития России [14, с. 589-596; 15]. Примечательно, что как неославянофил С. Шарапов сформировался и, соответственно, выступил с упомянутыми выше идеями после 1896 г., это стало прямым его интеллектуальным ответом на реформы С. Ю. Витте. В самом конце XIX в. С. Шарапов выступил с концептуальными идеями низкой социальной эффективности формировавшейся в России индустриальной системы. По его мнению, это выражалось в первую очередь в работе российского промышленного капитала, включая железнодорожный комплекс, на Запад, в результате чего прибыль получали западные общества. В этой связи С. Шарапов выступил за крестьянско-общинную хозяйственную систему, над которой стояла бы сильная монархия. То есть свобода русского народа виделась мыслителю в первую очередь в избавлении от гнета западного капитала, встроенного в российскую экономическую систему во многом стараниями С. Ю. Витте и всем его вестернизированным предшественникам во власти, включая Петра I.

В 1898 г. С. Ф. Шарапов выступил с идеей федерализации Российской империи, когда большинство русских правых радикалов выступали за укрепление централизма. После 1898 г. С. Ф. Шарапов публикует свои основные работы в форме литературных произведений-утопий, наиболее яркая из них была опубликована в 1902 г. под названием «Через полвека» [16].

С. Ф. Шарапов критиковал С. Ю. Витте за денежную реформу, главным пунктом которой был золотой стандарт $[17$, с. 130]. Как считал С. Ф. Шарапов, если Россия не избавится от золотых, или международных денег, то ее ожидает мрачной будущее - стать крупным должником и быть разоренной [Там же. С. 133]. Главной целью С. Ф. Шарапова как экономиста была разработка мер по выводу России из-под финансовой зависимости от Запада. Главным злом для России в этой связи С. Ф. Шарапов видел финансовые реформы Александра II, в результате которых государство в России утратило контроль над денежным обращением.

Либеральную теорию конкуренции (последнюю А. Смит и Д. Рикардо считали высшим благом для цивилизованного общества) С. Ф. Шарапов резко критиковал, обозначив конкуренцию как постоянную борьбу эгоизмов, которая изматывает общество. Именно конкуренция порождает борьбу социальных групп, классов и народов друг против друга, как считал С. Ф. Шарапов. В этой связи уместно вспомнить Великую депрессию как продукт слабо ограниченной конкуренции и ее последствия, которые отчасти стали причиной Второй мировой войны. Таким образом, по С. Ф. Шарапову, конкуренция провоцирует в людях пробуждение низменных диких эмоций, что ведет в итоге к распаду общества и к состоянию «войны всех против всех». России, по его мнению, такой путь должен быть противопоказан.

Идеи С. Ф. Шарапова отчасти перекликались с программными документами леворадикальной (на первый взгляд) организации Народная воля, два бывших ярких участника которой - Владимир Грингмут и Лев Тихомиров (бывший соратник П. Л. Лаврова) - стали к 1890 г. праворадикальными авторами. В 1888 г. Л. А. Тихомиров официально отрекся от революционных идей, получил помилование и незадолго после этого вернулся из политической эмиграции в Россию. 


\section{Против западных ценностей, С. Ю. Витте и революции}

Нам более интересен Л. А. Тихомиров, так как в период революционных событий 1905-1907 гг. он выступал против партийной парламентской системы, предлагая заменить ее представительством гражданских групп (корпоративная модель парламентаризма). Затем совместно с П. А. Столыпиным Л. А. Тихомиров участвовал в разработке рабочего законодательства, процесс чего продолжился после гибели знаменитого российского реформатора.

Как пишет в предисловии к своей работе, подготовленной в середине 1890-х гг., Л. А. Тихомиров, идея демократии привела к парламентаризму, а затем и к распространению в западных обществах социалистических идей $[18$, с. 3]. В конце предисловия к упомянутой выше книге Л. А. Тихомиров формулирует одно из своих основных положений: «Правильное и гармоническое сочетание в государстве основных элементов власти, без сомнения, составляет залог полноты жизни государства. Но дело в том, что наше время именно менее всего думает о таком сочетании. Сверх того, позволю себе остаться при убеждении, что сочетание монархического, аристократического и демократического элементов никак не может быть производимо собственно в верховной власти, которая, по существу, может быть только едина и нераздельна. Это сочетание возможно лишь в организации управления, а потому наиболее достижимо, полагаю, именно при неограниченной монархии как такой форме верховной власти, которая допускает наиболее спокойное искание общественного блага при наибольшей свободе от эгоистических стремлений тех или иных классов народа» [18, с. 7].

Источником бед в историко-географическом пространстве Л. А. Тихомиров видит французское интеллектуальное либерально-демократическое движение конца XVIII в. [Там же. C.11-12], которое опиралось на концепцию естественного права, на базе чего и возникла концептуальная идея всеобщего равенства - основной постулат Великой французской буржуазной революции. Таким образом, исторический горизонт кризиса не самой России, но христианских обществ в целом Л. А. Тихомиров отодвинул далеко от границ России на Запад и - на примерно сто лет. Однако этот кризис, по Л. А. Тихомирову, стал развиваться в направлении ухода от идеалов XVIII века в сторону социального демократизма, который готов был перейти в анархизм [Там же. С. 14].

Идеалы порочного, в понимании Л. А. Тихомирова, XVIII в. (события во Франции конца этого века он переносит почему-то на всю Европу XVIII столетия) базировались, как и само христианство, на вере, в рамках новой веры отрицался только духовный мир. Нельзя не согласиться с Л. А. Тихомировым, что понятие «народной воли» является метафизическим [Там же], очень напоминающим библейскую волю Бога. Мыслитель считает западный индивидуализм порождением социально-философской мысли Европы XVIII в., ассоциируя индивидуализм с атеизмом и рассматривая его как деструктивное явление, ведущее к распаду общества на базе роста отчужденности индивида от общества.

Суть интеллектуальной революции XVIII в. Л. А. Тихомиров видит в создании для индивидов такой установки к деятельности, как стремление к постоянному совершенствованию, что в итоге ведет к перманентной революции, как утверждал И. Аксаков. В этом смысле общество XVIII-XIX вв. является, по Л. А. Тихомирову, уникальным, и Запад этого периода совершенно не похож на античность, откуда европейцы заимствовали демократию, античный человек был консервативен, по Л.А.Тихомирову, он не стремился ничего кардинально менять [Там же. С. 20]. И далее Л. А. Тихомиров 
противоречит сам себе, утверждая, что в конце XVIII в. на Западе была предпринята попытка построить новое общество, но она не удалась, так как принципы Просвещения на практике стали плохо работать, поэтому общество вернулось к старому состоянию [Там же. C. 21]. Отсюда можно сделать вывод, что нет никакой перманентной революции, которую приписывал Западу И. Аксаков.

Далее Л.А. Тихомиров в своем отрицании партийной системы опирается на слова Ж.-Ж. Руссо [Там же. С. 22], который тоже выступал против политических объединений, которые нарушают волю народа, но в то же время именно Ж.-Ж. Руссо был одним из самых главных инициаторов интеллектуальной революции XVIII в. Л. А. Тихомиров, отталкиваясь от политологических идей Ж.-Ж. Руссо, высказывает идею, что воли партий подменяют народную волю, и здесь мыслитель снова винит Великую французскую буржуазную революцию, которая заменила волю народа частной волей, то есть интересами политических партий, выросших из самой структуры Конвента [Там же]. В ходе рассуждений Л. А. Тихомирова четко прослеживается идея - отгородить Россию от западных парламентаризма и системы ценностей в целом, инструментом к чему он видел русский монархический строй.

Если Л. А. Тихомиров теоретизировал русский правый радикализм, отталкиваясь от негативного, на его взгляд, опыта Запада, то Владимир Андреевич Грингмут больше интересовался практикой и вопросами русской истории, являясь при этом профессиональным историком и филологом. В. А. Грингмут выступил основателем Русской монархической партии (образована 24 апреля 1905 г.), он считается одним из основателей черносотенного движения. В. А. Грингмут - политик необычной судьбы: он вырос в лютеранской немецкой семье, начал карьеру как преподаватель древнегреческого языка, православие принял в 1878 г., подданство - в 1876 г. Где-то на рубеже 1860-1870 гг. В. А. Грингмут познакомился с М. Н. Катковым, последний, несомненно, оказал на него сильное влияние. Считается, что правым радикалом В. А. Грингмут стал под влиянием революционных событий января 1905 г. Но обвинения С. Ю. Витте в провокации своей экономической политикой социальных кризисных процессов в российском обществе указывают на генетическую связь воззрений В. А. Грингмута с негосударственными течениями правых радикалов. Важной особенностью личности В.А. Грингмута была сильная религиозность (нетипичная даже для подавляющего большинства русских верующих интеллектуалов того времени), которая особо стала явной, когда он занял должность директора Лицея Цесаревича Николая в 1894 году.

Идеалом из числа современников был для В. А. Грингмута Александр III, которого он считал истинно русским императором $[19$, с. 20]. Здесь очевиден примат личности в истории, что характерно для многих консерваторов. Но, что отрывает В. А. Грингмута от старой правой радикальной традиции, он категорически отказывается отождествлять реформы Петра I с вестернизацией России и с либерализмом, утверждая вполне справедливо, что, так как Петр Великий не демонтировал самодержавие, то и такое отождествление неверно [Там же. С. 22]. В. А. Грингмуту не нравилось в российских либералах их стремление перенести в Россию политическую нестабильность [Там же. С. 23], вытекающую из самого порядка устройства европейских обществ.

Рассуждая о сущности политики Петра I, B. А. Грингмут впадает в противоречие, он пишет, сравнивая Петра Великого с Екатериной II: «Заслуга Екатерины Великой пред Россией заключается в том, что она сама, всей душой и всем умом проникшись не только государственным, но и национальным величием своего второго отечества, заставила, вместе с тем, и Европу преклониться пред этим величием и возбудила в своих подданных государственное и национальное самосознание, как необходимое условие 
для существования и развития великого народа. Этим самосознанием был в свое время преисполнен и Петр Великий. Но он в России был почти одинок. Он собрал вокруг себя лишь небольшую, сравнительно, стаю птенцов, которым сообщил свою пламенную веру в великое мировое призвание России. Все почти остальные его подданные относились более или менее скептически к его великим преобразованиям, а Европа смотрела на него как на исторический курьез, как на баловня судьбы, со смертью которого Россия, забыв об его новшествах, снова вернется к своему прежнему, внеевропейскому существованию [Там же. С. 24]». Получается, что Петр I был истинно русский монарх, но понимало его меньшинство, то есть его преобразования шли вопреки воле большинства.

В. А. Грингмут четко выводит континуитет в развитии России от киевских князей до практически его времени, не видя сильных разрывов, и этот разрыв наступил при С. Ю. Витте, который усугубил, по В. А. Грингмуту, положение России, убедив Николая II выпустить Манифест 17 октября [Там же. С. 12]. Следующий, не менее тяжелый упрек В. А. Грингмута в адресу С. Ю. Витте - это «церковный переворот», то есть ослабление ограничений прав неправославных в России [Там же. С. 149]. Третье обвинение в адрес С. Ю. Витте - реформы образования, разрушившие, по мнению В. А. Грингмута, русскую школу. Почему? В. А. Грингмут считал, что правом на открытие частных школ воспользуются евреи, в руки которых попадет российское образование [Там же. С. 217]. Далее в этой связи В. А. Грингмут называет С. Ю. Витте ставленником масонов и евреев [Там же. С. 218]. Таким образом, по В. А. Грингмуту, причины леворадикального оппозиционного движения и революции не экономические по своей сути. Тем не менее В.А. Грингмут признает необходимость усовершенствования рабочего и крестьянского законодательств, соответственно, социально-экономические проблемы России и ее потребность в реформах им не отрицаются [Там же. С. 368-369]. В частности, В. А. Грингмут отмечал острую проблему малоземелья крестьянства [Там же. С. 372]. В этой связи он предлагает улучшения в сфере землепользования (мера, предлагавшаяся земством еще задолго до революции 1905 года), далее - переселение на Восток [Там же. С. 373] (инструмент, известный в Российской империи еще со времен Екатерины II). Не будучи экономистом, В. А. Грингмут все-таки понимал, почему вторая мера по борьбе с малоземельем плохо работала, основанные в периферийных регионах крестьянские хозяйства продолжали оставаться малоземельными и нетоварными в большинстве своем из-за дефицита у крестьян капитала и мотивов к созданию крупных хозяйств [Там же. С. 374]. В этой связи В. А. Грингмут предложил переселять на Восток также и помещиков.

Интересны рассуждения В.А. Грингмута, которые он делает от имени Русской монархической партии, о пути российской экономической политики и причинах кризиса российской экономики, который предшествовал революции 1905 года. 70 \% населения страны было занято в сельском хозяйстве, которое оказалось перед началом XX в. в сильной зависимости от мирового рынка зерна, цены на зерновые за рубежом стали падать, что привело к затяжным кризисным процессам в аграрном секторе Российской империи. Возникший в результате данных процессов дефицит капитала на селе привел к застою в аграрном развитии России, что в итоге спровоцировало серию неурожаев [Там же. С. 375]. В этой связи В. А. Грингмут счел необходимым прямое вмешательство государства в экономику сельского хозяйства, к которому оно, по его мнению, пренебрежительно относилось из-за ориентации экономической политики на развитие промышленности. 
В промышленной политике государства В. А. Грингмут в духе Фридриха Листа призывал к усиленному интернационализму, вплоть до искусственного создания новых отраслей [Там же. С. 376]. Далее В. А. Грингмут считал необходимым создание специальных банков для кредитования промышленности [Там же]. Узость кредитования промышленности, по В. А. Грингмуту, сильно ударила по малым и средним предприятиям [Там же]. Таким образом, В. А. Грингмут признавал, что Россия пришла в XX в. хозяйственно не обустроенной, реформы С. Ю. Витте только способствовали раскрепощению революционных сил, но не содействовали ее оздоровлению на фоне роста государственных расходов и, соответственно, налогообложения простых россиян, что В.А.Грингмут считал экономическим бедствием для России [Там же. С. 376-377]. То есть, период С. Ю. Витте и немного до него и уже после него и есть то безвременье, из которого России надлежало выходить посредством применения в государственной политике методик Петра I и Екатерины II.

Ярким участником праворадикального движения в России был Павел Федорович Буланцель, по профессии юрист, он работал адвокатом, явился одним из основателей Союза русского народа (СРН) и занимал должность редактора центрального печатного органа СРН - газеты «Русское знамя».

По П. Ф. Буланцелю, политика С. Ю. Витте носила характер, ущемлявший права русских [20, с. 35-38]. Манифест 17 октября 1905 г. П. Ф. Буланцель считал разрушительным для самодержавия и России актом [Там же. С. 37]. По мнению П. Ф. Буланцеля, в основе мотивов социал-демократов лежал развал государства с целью личного обогащения.

У П. Ф. Буланцеля были конкретные претензии к правительству С. Ю. Витте. Вопервых, это слишком долгое судопроизводство, по финансовым искам истцам приходилось, как он пишет, дожидаться результатов по 5-6 лет [Там же. С. 40]. Во-вторых, циркуляр Министерства юстиции, что нельзя привлекать к уголовной ответственности организаторов стачек, что противоречило законодательству Российской империи, спровоцировал усиление революционного движения [Там же. С. 41], по сути, здесь П.Ф.Буланцель напрямую обвиняет либерализм С. Ю. Витте в развитии революции 1905 года. И самого С. Ю. Витте П. Ф. Буланцель считал ставленником американских банкиров.

П. Ф. Буланцель выступал категорически против парламентской демократии и демократии в целом, опираясь при этом на английского историка Маколея, который высказал такое мнение в пересказе П. Ф. Буланцеля, что «всеобщая равная подача голосов - величайшее зло, так как в каждом государстве больше недовольных дурных и глупых людей, чем довольных, умных и добрых, а поэтому, предоставляя всем без разбора право голоса, отдают судьбу государства в руки необразованного, глупого и порочного большинства [Там же. С. 48].

Наиболее полно причины своего негативного отношения к демократии П. Ф. Буланцеля отражены в следующей его цитате: «Зачем Европа нам хочет навязать свою форму правления, благодаря которой гниет и разваливается австро-венгерская монархия Габсбургов? Из любви к нам? Из желания облагодетельствовать наш русский народ? Какая наивность! Да неужели русские люди все еще не понимают, что вся эта революционная вакханалия нужна для того, чтобы вырвать у Царя конституцию, при которой всякие Ротшильды могли бы печатать у нас в России свои бумажные деньги, как они печатают их в Австрии [Там же. С. 50]». Таким образом, П. Ф. Буланцель считал демократию и демократические революции инструментом в руках интернационального капитала, примерно так буржуазную демократию представляли и большевики. 
Другим достаточно интересным автором в рамках русской праворадикальной мысли был Андрей Сергеевич Вязигин, историк, руководитель фракции правых в III Государственной Думе. Как и практически все правые радикалы того времени, А. С. Вязигин считал С. Ю. Витте «злым гением», спровоцировавшим революционный процесс. А. С. Вязигин вполне справедливо считал, что С. Ю. Витте не знал и не мог знать мнения большинства русского народа, но от имени большинства проводил в жизнь свои реформы [21, с. 274].

Наиболее четко А. С. Вязигин выразил свое отношение к административной реформе С. Ю. Витте в следующих словах: ««На наших глазах происходит не освященное народным желанием преобразование России, а чисто бюрократический переворот, по свидетельству даже его виновника, не имеющий корней в народном сознании... Тяжкие испытания надвигаются благодаря этому на наше Отечество, и не общим ликованием, спутником удовлетворения чаяний подлинного большинства, а ужасами погромов, избиений, вооруженных столкновений ответила страна на первые шаги нового правительства, которое вынуждено было при содействии Св. Синода объяснять народу, что он уже «созрел и достоин свободы мужа»» [Там же. С. 275].

А. С. Вязигин считал, что демократия в России невозможна в силу уже такого фактора, как безграмотность 81 \% населения, при таком условии развитие политической системы по западному пути неминуемо должно было привести, по его мнению, к смуте [Там же. С. 287].

Как и все правые радикалы, А. С. Вязигин видел вывод России из затяжного экономического кризиса в помощи крестьянству, в первую очередь это касалось наделения землей из государственного фонда малоземельных крестьян. Однако, помимо этого, он предлагал обеспечить новых поселенцев средствами производства на льготных условиях [Там же. С. 284]. А. С. Вязигин предложил также такой программный пункт оздоровления российской экономики, как обобществление природных богатств, а также ограничение доступа к ним иностранцев. Если брать во внимание и другие программные пункты в экономической сфере, предложенные А. С. Вязигиным, то его идеи по оздоровлению народного хозяйства России напоминают дирижизм во Франции незадолго до Второй мировой войны, разумеется, между ними нет прямой связи, но эти идеи, как говорится, витали в воздухе еще до Первой мировой войны. Для нас важно и другое: А. С. Вязигин считал экономику России начала XX в. больной.

\section{Заключение}

Русский правый радикализм прошел сложный путь от утопий С. Ф. Шарапова к вполне вписывавшимся в современные политические идеологические схемы идеям, которые в экономической части напоминают французский дирижизм 1930-х гг. Если левые радикалы видели выход из кризиса и отставания России в сломе всего государственного механизма, то правые радикалы считали необходимым вернуться к старой, существовавшей до С. Ю. Витте модели государственной политики. При этом правые радикалы признавали факт отставания России, однако оно не ассоциировалось у них строго с хроническим дисбалансом в народном хозяйстве в пользу сельского хозяйства, последнее они видели основой экономики.

Таким образом, реформы С. Ю. Витте разрезали российский исторический процесс на «до» и «после», второе виделось правым радикалам в мрачном свете, если правительство не остановило бы либерализацию общества и экономики. Политика С. Ю. Витте, по мнению правых радикалов, была направлена на усиление зависимости 
России от иностранного капитала, в этом смысле русских правых радикалов можно считать первыми в нашей стране антиглобалистами, так как торжество рыночной экономики на Западе и за его пределами рассматривалось ими в качестве инструмента подчинения народов интернациональному капиталу, центры которого находились в Англии и США. В этом смысле и парламентская демократия, основанная на многопартийности, тоже являлась одним из инструментов в руках англо-американского капитала.

Правые радикалы верили в народ, который, по их мнению, должен был одуматься и выступить против революционеров. Но практически до начала 1905 г. праворадикальная интеллигенция была замкнута в себе, не выходя за пределы своих кружков. Здесь содержится главное уже практическое противоречие данного движения в российской политике до 1917 года, что объясняет и резкое снижение популярности его идей после Февральской революции, не говоря уже о времени Октябрьской революции. В этой связи вполне понятно, что В.А. Грингмут, будучи оторванным в силу ряда социальных причин от народа, возлагал надежды больше на монархию, чем на русских крестьян и рабочих, то же самое касается и других представителей правого радикального движения. Вполне понятно также, почему многие из них, в отличие от утописта С. Ф. Шарапова, считали эпоху Петра I великим временем, позитивным образом преобразовавшим Россию, эта часть русской гуманитарной интеллигенции была органически связана с идеалами России XVIII в. и начала XIX в.

В работах правых радикалов содержится одно важное противоречие: они признают монархию самой совершенной моделью государственного устройства, но в то же время признают, обращаясь к примеру Николая II, что самодержец способен допускать серьезные ошибки, ведущие к разрушению самого монархического строя, особенно это касается ситуации с Манифестом 17 октября 1905 года. В этой связи правые радикалы предлагали фактически ограничить власть императора совещательным органом, состоящим из лучших людей, то есть из консерваторов.

Второе крупное противоречие, содержащееся в теориях правых радикалов, выросло из славянофильства, это указание на позитивность, по сравнению с Западом, пути развития России, начиная с киевских князей, но при этом ультраправыми в начале $\mathrm{XX}$ в. признавался факт отставания России, которое вытекало отчасти из установившейся во время Великих реформ зависимости России от иностранного капитала. Финансовая зависимость от Запада возникла, очевидно, до Николая II, что понимали и неославянофилы, но, несмотря на это, продолжали идеализировать Александра III, как и всю русскую монархию. В этой связи праворадикальное движение фактически предлагало революцию, только националистическую, при сохранении зависимого от них института императорской власти, и здесь это политическое движение немало напоминает японских ультраправых.

\section{Ссылки / References}

1. Куприянов В. А. Идея революции в русском и западном классическом либерализме // Революция и эволюция: модели развития в науке, культуре, обществе: Труды II Всероссийской научной конференции / Под общей ред. И. Т. Касавина, А. М. Фейгельмана. Нижний Новгород: Красная ласточка, 2019. С. 266-268.

2. Лукьянов М. Н. Российская радикальная правая накануне Первой мировой войны глазами британского историка: заметки на полях книги Джорджа Джилберта «Радикальная правая в позднеимперской России: мечты о подлинном отечестве?» // Вестник Пермского университета. 2018. История. Выпуск 3 (42). С. 135-140. 
3. Возилов В. В. «Левый» и «правый» радикализм в идеософии и практике русской интеллигенции в начале XX в. // Исторические, философские, политические и юридические науки, культурология и искусствоведение. Вопросы теории и практики. Тамбов: Грамота, 2013. № 7 (33): в 2-х ч. Ч. II. С. 22-24.

4. Ц Цивилизационный суверенитет России: проблемы и дискуссии / А. Л. Золкин, П. П. Марченя, С. Р. Аблеев, С. И. Кузьминская. М.: ИПЛ, 2017. 212 с.

5. Мультатули П. В. Кругом измена, трусость и обман. Подлинная история отречения Николая II. М.: АСТ, 2012. 443 с.

6. Мультатули П. В. Николай II. Дорога на Голгофу. М.: АСТ. Астрель, 2010. 637 с.

7. Litvin A., Keep J. Stalinism. Russian and Western views at the turn of the millennium. London: Routledge, 2005. 248 p.

8. Булдаков В. П. Имперство и российская революционность (критические заметки) // Отечественная история. 1997. № 1. С. 42-60.

9. Булдаков В. П. Октябрь и XX век // Международная жизнь. 1997. № 11. С. 72-88.

10. Булдаков В. П. Марксизм, Ленин, революция: метаморфозы великой легенды // Российская история. 2020. № 2. С. 3-24.

11. Зверев В. В. Ленин: социализм, народники и мировая революция // Российская история. 2020. № 2. C. 31-34.

12. Катков М. Н. Собрание передовых статей Московских ведомостей. 1864 год. М.: Издание С. П. Катковой, 1897. 841 с.

13. Изместьева Г. П. Михаил Никифорович Катков // Вопросы истории. 2004. № 4. С. 71-92.

14. Черная сотня. Историческая энциклопедия / Под ред. О. А. Платонова. М.: Крафт+, 2008. $640 \mathrm{c}$.

15. Суслов М. Д. Принцип редукции картины мира в славянофильской утопии С. Ф. Шарапова // Международный журнал исследований культуры. 2012. № 4 (9). С. 56-65.

16. Шарапов C. Ф. Через полвека // Lib.Ru: Библиотека Максима Мошкова [сайт]: URL: http://az.lib.ru/s/sharapow_s_f/ (дата обращения: 27.07.2021).

17. Шарапов С. Ф. Россия будущего / Сост., предисл., примеч., именной словарь А. Д. Каплина; отв. ред. О. А. Платонов. М.: Институт русской цивилизации, 2011. 740 с.

18. Тихомиров Л. А. Демократия либеральная и социальная. М.: Ленанд, 2019. 200 с.

19. Грингмут В. А. Объединяйтесь, люди русские! / Сост. А. Д. Степанов; отв. ред. О. А. Платонов. М.: Институт русской цивилизации, 2008. 544 с.

20. Булацель П. Ф. Борьба за правду / Сост., предисл., комментарии Д. И. Стогова; отв. ред. О. А. Платонов. М.: Институт русской цивилизации, 2010.704 с.

21. Вязигин А. С. Манифест созидательного национализма / Сост. и комментарии А. Каплина и А. Степанова; отв. ред. О. А. Платонов. М.: Институт русской цивилизации, 2008. 400 с. 